$\left(\delta^{13} \mathrm{C}\right.$ increases) and vice versa (Williams and Flanagan, 1996). However, the effect of recycled methane on $\delta^{13} \mathrm{C}$ of Sphagnum biomarkers has the opposite relationship with moisture. When the peatland is wetter, more methane produced at depth is respired by methanotrophs that are symbiotic with Sphagnum, the resulting low- $\delta^{13} \mathrm{CCO}_{2}$ is assimilated by Sphagnum and recorded in lower $\delta^{13} \mathrm{C}$ of Sphagnum biomarkers. During drier conditions, the reverse occurs (Nichols et al., 2009; Raghoebarsing et al., 2005). These competing factors necessitate careful interpretation of Sphagnum biomarker $\delta^{13} \mathrm{C}$ measurements.

\section{Conclusions}

Isotopic and organic geochemistry analyses of peats are valuable approaches for understanding past climatic and environmental change. The complexity of peatlands requires a multi-proxy approach to fully exploit the paleoenvironmental signatures contained within peat archives. Further research is also needed into the factors controlling the isotopic composition of different plant compounds (e.g., evaporative effects in plant waxes vs cellulose) to better understand the environmental signatures contained within them.

\section{References}

Daley, T.J., Barber, K.E., Street-Perrott, F.A., Loader, N.J., Marshall, J.D., Crowley, S.F., Fisher, E.H., in press: Holocene climate variability revealed by oxygen isotope analysis of Sphagnum cellulose from Walton Moss, northern England, Quaternary Science Reviews, doi:10.1016/j.quascirev.2009.09.017

McClymont, E.L., Mauquoy, D., Yeloff, D., Broekens, P., van Geel, B., Charman, D.J., Pancost, R.D., Chambers, F.M. and Evershed, R.P., 2008: The disappearance of Sphagnum imbricatum from Butterburn Flow, UK, The Holocene, 18: 991-1002.

Nichols, J., Booth, R.K., Jackson, S.T., Pendall, E.G. and Huang, Y., 2010 Differential hydrogen isotopic ratios of Sphagnum and vascular plant biomarkers in ombrotrophic peatlands as a quantitative proxy for precipitation--evaporation balance, Geochimica et Cosmochimica Acta, 74: 1407-1416.

Pendall, E., Markgraf, V., White, J.W.C., Dreier, M. and Kenny, R., 2001 : Multiproxy record of late Pleistocene-Holocene climate and vegetation changes from a peat bog in Patagonia, Quaternary Research, 55: 168-178.

Skrzypek, G., Kaluzny, A., Wojtun, B. and Jedrysek, M.-0., 2007: The carbon stable isotopic composition of mosses: A record of temperature variation, Organic Geochemistry, 38: 1770-1781.

\title{
Peat cellulose isotopes as indicators of Asian monsoon
}

\section{variability}

BING Hong ${ }^{1}$, M. UChIDA ${ }^{2}$, X.T. Leng $^{3}$ AND Y.T. Hong ${ }^{1}$

'State Key Laboratory of Environmental Geochemistry, Institute of Geochemistry, Chinese Academy of Sciences, Beijing, China; hongbing@vip. skleg.cn

Environmental Chemistry Division, National Institute for Environmental Studies, Tsukuba, Japan; ${ }^{3}$ Institute of Peatmire, Northeast Normal University, Changchun, China

\section{Stable isotopes in peat cellulose provide records of Asian monsoon variability in the Holocene and suggest persistent teleconnections between the Asian monsoons and North Atlantic climate variability.}

\section{Peat cellulose isotopes as proxy climate indicators}

A practical proxy for climate reconstruction for the Holocene epoch should be able to span about $10 \mathrm{ka}$ with decadal to centennial time resolution. Over the last 20 years oxygen and carbon isotope analysis of peat cellulose has been developed as a Holocene paleoclimate proxy (Brenninkmeijer et al., 1982; Hong et al., 2000, 2001; Ménot-Combes et al., 2002). Peat plant cellulose is a macromolecular polymer of interlinked dextroglucose molecules (Hong et al., 2009; and see McClymont et al., this issue), formed from oxygen atoms derived from the water used by the plant and carbon atoms derived from atmospheric $\mathrm{CO}_{2}$. The stable isotopic composition of cellulose oxygen and carbon is influenced by different physical and chemical processes. Oxygen isotopes $\left(\delta^{18} \mathrm{O}\right)$ in water molecules undergo temperature-dependent fractionation during condensation. Variations in $\delta^{18} \mathrm{O}$ of meteoric water are generally positively correlated with atmospheric temperature (Dansgaard, 1964). During photosynthesis, the $\delta^{18} \mathrm{O}$ signature of the source water is recorded in cellulose molecules. Source water for photosynthesis in many peatlands is primarily meteoric, although it may be enriched by evaporation. Vascular plants respond to variations in water availability and relative humidity by regulating the opening or closing of leaf stomata. This leads to changes in the stable carbon isotopic composition $\left(\delta^{13} \mathrm{C}\right)$ of atmospheric $\mathrm{CO}_{2}$ utilized in photosynthesis (Francey and Farquhar, 1982; Schleser, 1995). The amount of rainfall is also negatively correlated to the plant $\delta^{13} \mathrm{C}$ value; the larger the amount of rainfall, the smaller the $\delta^{13} \mathrm{C}$ value (Lee et al., 2005; Wang et al., 2008). Therefore, information on climatic changes is preserved in the $\delta^{18} \mathrm{O}$ and $\delta^{13} \mathrm{C}$ values of peat plant cellulose. Finally, plant cellulose is highly resistant to decomposition. Both cellulose and its isotopes are highly stable over periods of approximately $10^{5}$ years (Briggs et al., 2000). Peat plant cellulose isotopes therefore have significant potential as a bioindicator of paleoclimatic changes. Here we summarize the contribution of peat cellulose isotopes to the reconstruction of East Asian monsoon variability during the Holocene.

\section{Spatial variation of the EASM and peatland distribution}

Recent advances in extraction and purification of cellulose from bulk peat samples have allowed application of peat cellulose isotopes (Hong et al., 2000, 2001) to reconstruct the history of the Asian sum- mer monsoon (e.g., Hong et al., 2009). Peat deposits of northern China are largely dominated by sedges, so the isotopic sig-

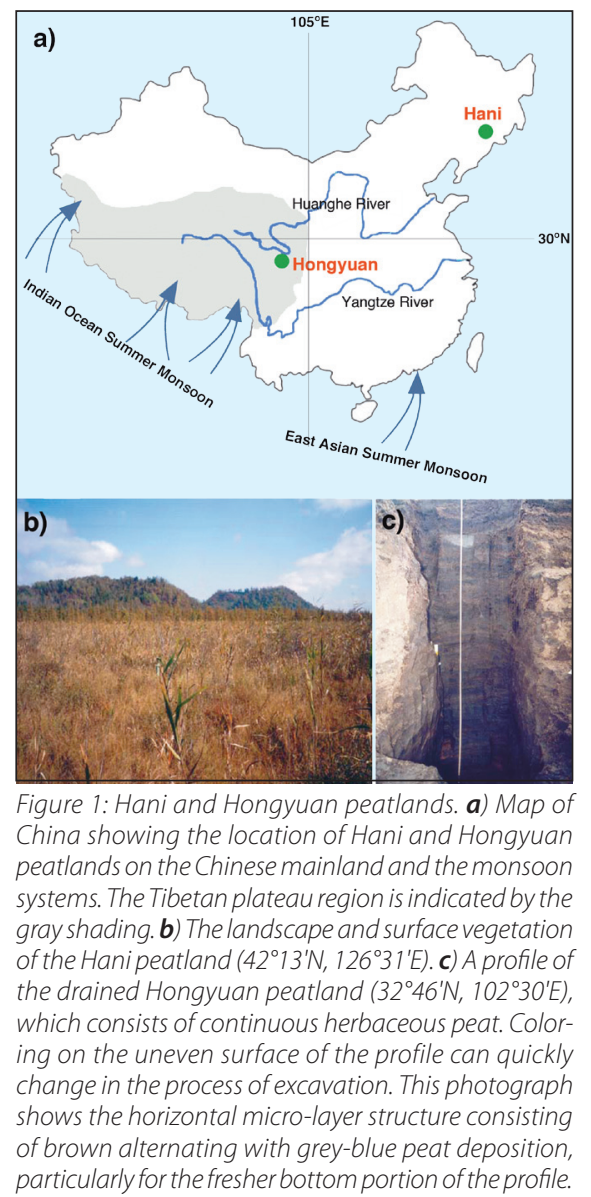


nal is not influenced by plant composition changes to any great degree.

The Asian summer monsoon includes two monsoonal systems, the Indian Ocean summer monsoon (IOSM) and the East Asian summer monsoon (EASM). Although they form independently of each other, these systems play an important role in water vapor transport and summer precipitation on the East Asian continent (Tao and Chen, 1987). In general, the EASM dominates east of $105^{\circ} \mathrm{E}$ longitude, whereas the IOSM has greater influence west of that longitude, particularly in the Tibetan plateau region (Fig. 1; Sun 1996, Hong et al., 2006).

There is significant interannual variability in rainfall amount and monsoonal strength within the EASM domain. This variability is controlled by intensity and position of the western Pacific subtropical high (STH) and by sea surface temperature (SST) variation in the equatorial Pacific. When SSTs take on an El Niño-like pattern, the STH tends to strengthen. This is accompanied by a strengthened Intertropical Convergence Zone, and stronger convection, especially in the tropical western Pacific. The STH over the western Pacific ocean shifts northward, leading to migration of a precipitation belt to the north of the Chinese continent. This results in an increase in rainfall in both the north and northeast regions of China, but at the same time, less rainfall in the middle and lower regions of the Yangtze River (Sun and Yin, 1999; Yin and Sun, 2000; Wu et al., 2003). In contrast, when SST variation in the equatorial Pacific takes on a $\mathrm{La}$ Niña-like pattern, the intensity of the STH tends to weaken, and the position of the STH over the western Pacific ocean moves south. This generally results in migration of a precipitation belt to the southern regions of the Chinese continent, leading to an increase in precipitation in southern China, but less rainfall in northern and northeastern China.

Only a strong EASM that originates from the South China Sea can expand to the northern regions of the East Asian subcontinent. Therefore, meteorologists commonly regard precipitation conditions in northern and northeastern China as representative of the variation in the strength of the EASM (Gao and Xu, 1962; Hong et al., 2006; Wang and Zhu, 2006). Fortunately, the most extensive, deepest and best-preserved peatlands occur in northeast China (for example, the Hani peatland) and in the Tibet plateau regions (e.g., the Hongyuan peatland) (Fig. 1). Peat cellulose stable isotopes in these two lo-

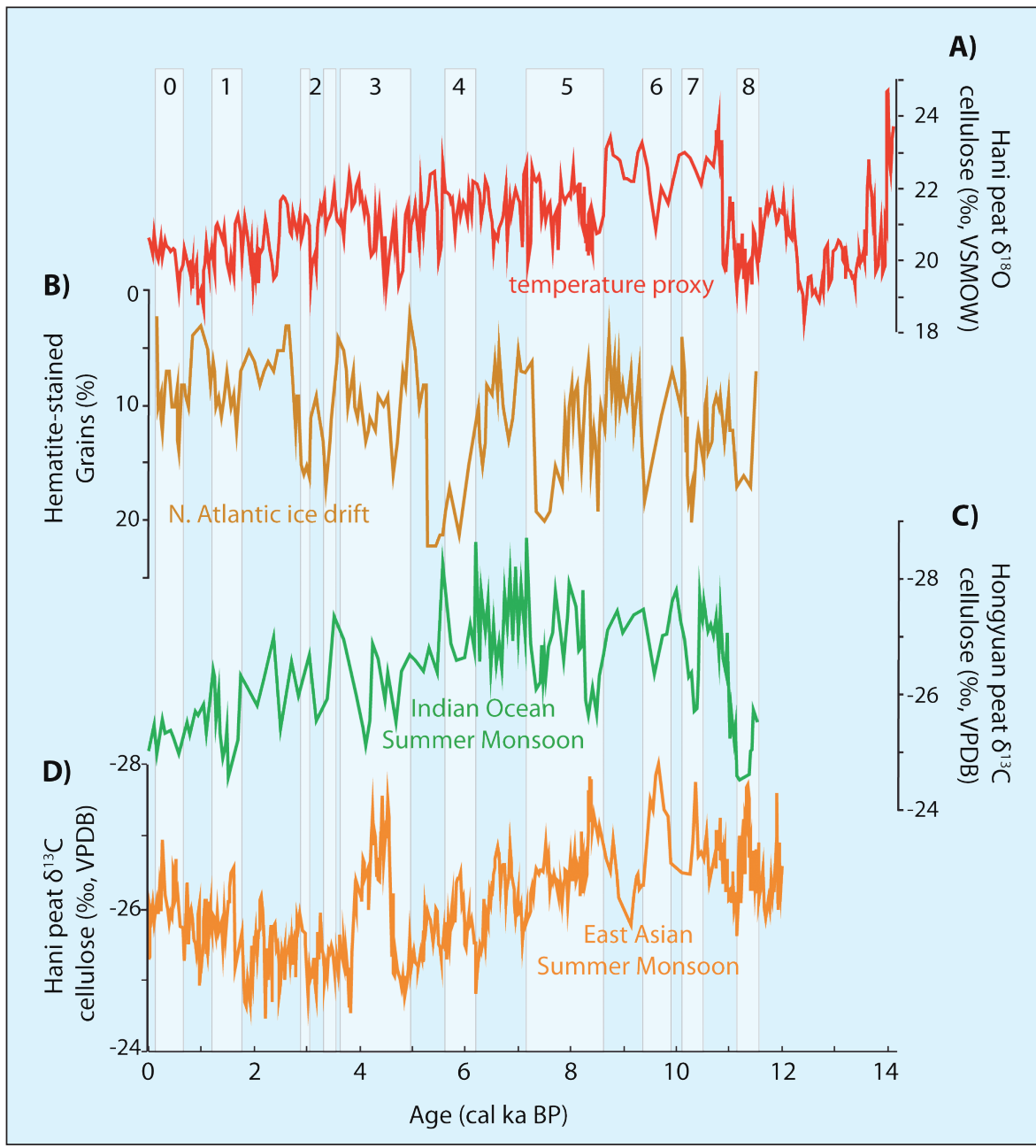

Figure 2: Comparison of the inverse phase variations between the two Asian monsoons and the climate changes of the North Atlantic and West Pacific Oceans. A) The $\delta^{18} \mathrm{O}$ temperature proxy record of the Hani peat cellulose (Hong et al., 2009). B) The drift ice record of the North Atlantic (Bond et al., 1997). C) Proxy record for the Indian Ocean summer monsoon (IOSM) from $\delta^{13} \mathrm{C}$ of the C. mulieensis cellulose in the Hongyuan peat (Hong et al., 2003). D) Proxy record for the East Asian summer monsoon (EASM) from $\delta^{13} \mathrm{C}$ of the Hani peat cellulose (Hong et al., 2005). Numbers from 1 to 8 indicate ice-rafted debris events of the North Atlantic, O indicates "Little Ice Age" event (Bond et al., 1997).

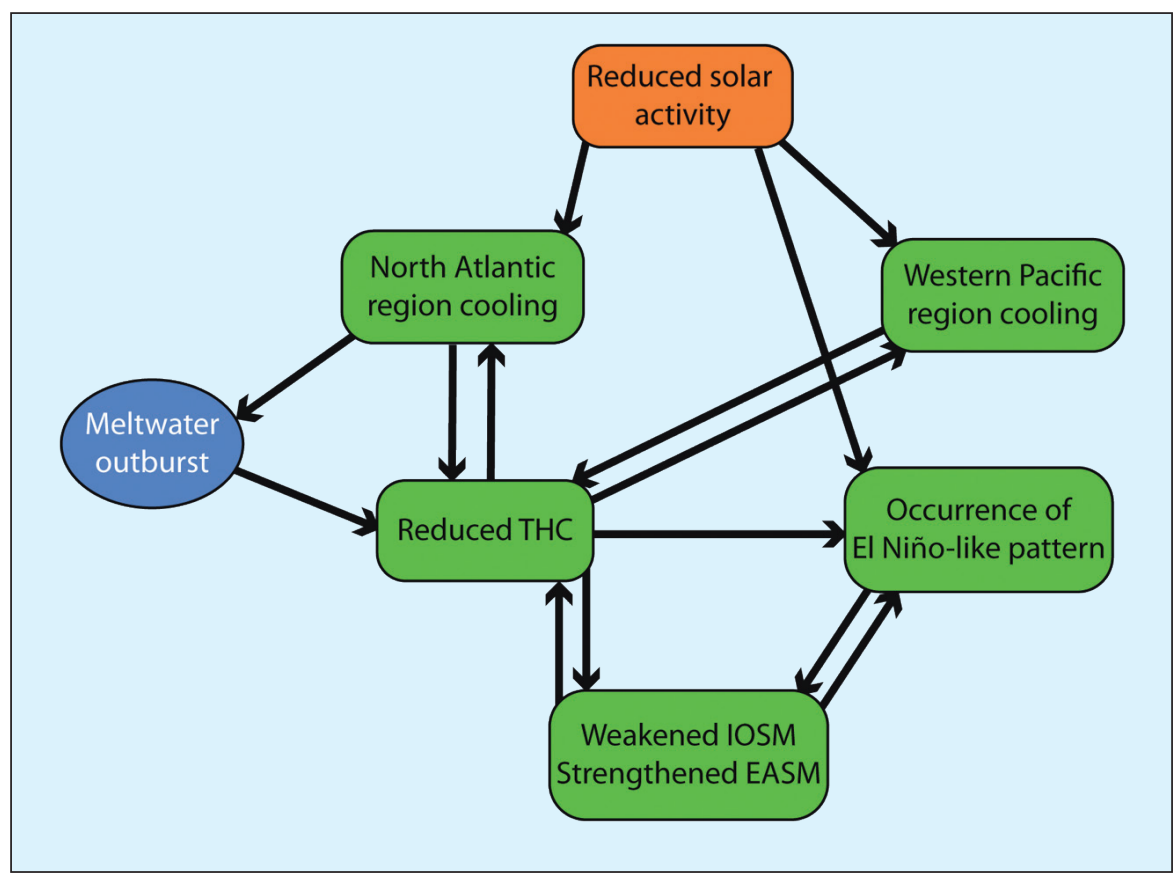

Figure 3: A conceptual model on global climate interconnections on centennial to millennial timescales during the period from the last deglaciation to the Holocene (Figure modified from Hong et al., 2009). In addition to synchronous abrupt temperature deterioration in the western North Pacific and North Atlantic regions, it also shows hypothesized interconnections between ice sheet variation at the high northern latitudes, ocean-atmospheric processes of the Equatorial Pacific, monsoonal activity in the middle-low latitudes, and solar activity. THC, IOSM, and EASM denote the ocean thermohaline circulation, the Indian Ocean summer monsoon, and the East Asian summer monsoon, respectively. 
cations therefore reflect variability in the EASM and IOSM respectively.

\section{Global connections of the Asian monsoon recorded in peat}

Comparison of the Hani and Hongyuan $\delta^{13} \mathrm{C}$ records has revealed the phenomenon of antiphase variations between the EASM and IOSM on centennial to millennial timescales (Fig. 2). Abrupt strengthening of the EASM and simultaneous abrupt weakening of the IOSM appear to have occurred at times that correspond to the nine abrupt ice-rafted debris events in the North Atlantic (Hong et al., 2003, 2005), suggesting global teleconnections between the North Atlantic, Pacific Ocean and monsoon systems throughout the Holocene. The anti-phase variations of the two Asian monsoons correspond to both reduced solar activity in the late Holocene and to meltwater events in the early Holocene. A conceptual model of global climate changes that summarizes the connections between ice sheet variations at high northern latitudes, oceanatmospheric process of the equatorial Pacific, monsoonal activity in the middlelow latitudes, and solar activity is shown in Figure 3. It remains for these interactive processes to be further examined and tested against new paleoclimate records. Peat cellulose isotope indicators could play an important role in this investigation because nearly all land regions affected by the processes mentioned above possess peatlands. A systematic global comparative study on peatland paleoclimatology would help test our hypotheses of monsoon variability as well as addressing other key paleoclimate questions (see e.g., Booth et al., this issue).

\section{References}

Hong, Y.T., Wang, Z.G., Jiang, H.B., Lin, Q.H., Hong, B., Zhu, Y.X., Wang, Y., XU, L.S., Leng, X.T. and Li, H.D., 2001: A 6000-year record of changes in drought and precipitation in northeastern China based on a $\delta^{13} \mathrm{C}$ time series from peat cellulose, Earth and Planetary Science Letters, 185: 111-119.

Briggs, D.E.G., Evershed, R.P. and Lockheart, M.J., 2000: The biomolecular paleontology of continental fossils, Paleobiology, 26: 169-193.

Hong, B., Lin, Q.H. and Hong, Y.T., 2006: Interconnections between the Asian monsoon, ENSO, and high northern latitude climate during the Holocene, Chinese Science Bulletin, 51: 11-19.

Sun, S. and Yin, M., 1999: Subtropical high anomalies over the Western Pacific and its relations to the Asian monsoon and SST anomaly, Advances in Atmospheric Sciences, 16: 559-568.

Hong, Y.T., Hong, B., Lin, Q.H., Shibata, Y., Zhu, Y.X., Leng, X.T. and Wang Y., 2009: Synchronous climate anomalies in the western North Pacific and North Atlantic regions during the last 14,000 years, Quaternary Science Reviews, 28: 840-849.

\title{
Peat as an archive of atmospheric pollution and environmental change: A case study of lead in Europe
}

\author{
François De Vleeschouwer ${ }^{1}$, G. Le Roux ${ }^{2}$ and W. Shotyk ${ }^{3}$ \\ 'Department of Ecology and Environmental Science, Umeå University, Sweden; francois.devleeschouwer@emg.umu.se \\ ${ }^{2}$ EcoLab (UMR 5245), National Center for Scientific Research, Université de Toulouse, France; ${ }^{3}$ Environmental Inorganic and Isotope Geochemis- \\ try Research Group, Institute of Earth Sciences, University of Heidelberg, Germany
}

\section{Inorganic geochemistry in peat deposits provides unique and valuable indications of human activities and consequent environmental changes.}

\section{European heavy metal pollution}

Ombrotrophic bogs are uniquely suited to provide records of natural and anthropogenic airborne particles because their surface layers are exclusively fed by atmospheric inputs (i.e., rain, snow, fog, dust), and hence offer the unique possibility to record atmospheric metal emissions at a relatively high time-resolution (centennial to decadal). Peat cores from such bogs are excellent continental archives of atmospheric lead $(\mathrm{Pb})$ deposition not only because they receive $\mathrm{Pb}$ solely from the air but also because they efficiently retain this metal despite their low pore-water $\mathrm{pH}$ (c. 4) and the seasonal variations in redox potential that should promote particle dissolution (e.g., Shotyk and Le Roux, 2005, and references therein). The high abundance of natural complex-forming organic acids guarantees the preservation of metal-bearing particles, especially lead.

It is of particular importance to document both background and actual metal fluxes because the atmospheric geochemical cycle of lead and other metals has been profoundly affected by human activities throughout the Northern Hemisphere for more than 3 ka (Nriagu, 1983). Human activities have significantly impacted the atmospheric emissions of a broad range of metals and metalloids (e.g., $\mathrm{Pb}$, copper $(\mathrm{Cu})$, zinc, cadmium, mercury $(\mathrm{Hg})$ ), as a result of the smelting of metal sulfide ores and the combustion of coal, both releasing particulates and aerosols (Pacyna et al., 2007, 2009). Given the ease by which it can be smelted and the number of possible industrial and commercial applications, $\mathrm{Pb}$ has been used by humans for more than 8 ka (Wertime, 1973). In addition, the stable isotopes of $\mathrm{Pb}$ allow "natural" $\mathrm{Pb}$ to be distinguished from various anthropogenic sources (lead ores, coal, gasoline), allowing one to track pollution sources and tackle the origin of long-range natural dust contributions during the Holocene.

Long-term $\mathrm{Pb}$ emissions over Europe have been unambiguously documented by analysis of peat cores from ombrotrophic bogs (e.g., Shotyk et al., 1998). Using $\mathrm{Pb}$ isotopes, Kylander et al. (2005) in Spain and Shotyk et al. (1998) in Switzerland have also shown significant variability in Saharan dust input over Europe during the Holocene. From a paleotoxicity point of view, the pre-anthropogenic emissions of $\mathrm{Pb}$-bearing particles are insignificant compared to late Holocene anthropogenic emissions. Moreover, their larger grain size (5-50 $\mu \mathrm{m}$ compared to $0.5 \mu \mathrm{m}$ for anthropogenic particles) and low solubility in natural conditions render them largely harmless for the environment and humans (Shotyk and Le Roux, 2005). The anthropogenic lead-bearing particles, due to their sub-micronic grain size, are easily incorporated in the environment and also in human beings by inhalation or ingestion. In addition, the amount emitted in the atmosphere, although fluctuating with climate and therefore representing a potential tracer for Holocene paleoclimatic changes, is negligible compared to the amount of anthropogenic lead-bearing particles emitted during the second half of the Holocene.

Geological archives are commonly employed to assess the extent of metal release to the environment, including the atmospheric fluxes and other predominant sources. During the past 50 years, bogs have become increasingly recognized as the best continental archives of atmospheric $\mathrm{Pb}$ deposition, especially in Europe (Fig. 1), a region that has contributed so much to global atmospheric pollution. A number of European bogs have yielded high-resolution reconstructions of atmospheric $\mathrm{Pb}$ deposition (e.g., Shotyk et al., 1998; Le Roux et al., 2004; De Vleeschouwer et al., 2009, and references 


\section{B. Hong, M. Uchida, X.T. Leng and Y.T. Hong}

Bond, G., Showers, W., Cheseby, M., Lotti, R., Almasi, P., deMenocal, P., Priore, P., Cullen, H., Hajdas, I. and Bonani, G., 1997: A Pervasive millennial-scale cycle in North Atlantic Holocene and glacial climates, Science, 278: 1257-1266.

Booth, R.K., Jackson, S.T. and Notaro, M., 2010: Using peatland archives to test paleoclimate hypotheses, PAGES news, 18(1).

Brenninkmeijer, C.A.M., Van Geel, B. and Mook, W.G., 1982: Variations in the D/H and ${ }^{18} \mathrm{O} /{ }^{16} \mathrm{O}$ ratios in cellulose extracted from a peat bog cove, Earth and Planetary Science Letters, 61: 283-290.

Briggs, D.E.G., Evershed, R.P. and Lockheart, M.J., 2000: The biomolecular paleontology of continental fossils, Paleobiology, 26: 169-193.

Dansgaard, W., 1964: Stable isotopes in precipitation, Tellus, 16: 436-468.

Francey, R.J. and Farquhar, G.D., 1982: An explanation of ${ }^{13} \mathrm{C} /{ }^{12} \mathrm{C}$ variations in tree rings, Nature, 297: 28-31.

Gao, Y.X. and Xu, S.Y., 1962: Some problems of East Asian Monsoon, pp. 1-49, Science Press, Beijing.

Hong, B., Lin, Q.H. and Hong, Y.T., 2006: Interconnections between the Asian monsoon, ENSO, and high northern latitude climate during the Holocene, Chinese Science Bulletin, 51: 11-19.

Hong, Y.T., Jiang, H.B., Liu, T.S., Zhou, L.P., Beer, J., Li, H.D., Leng, X.T., Hong, B. and Qin, X.G., 2000: Response of climate to solar forcing recorded in a 6000 -year $\delta^{18} \mathrm{O}$ timeseries of Chinese peat cellulose, The Holocene, 10: 1-7.

Hong, Y.T., Wang, Z.G., Jiang, H.B., Lin, Q.H., Hong, B., Zhu, Y.X., Wang, Y., Xu, L.S., Leng, X.T. and Li, H.D., 2001: A 6000-year record of changes in drought and precipitation in northeastern China based on a $\delta^{13} \mathrm{C}$ time series from peat cellulose, Earth and Planetary Science Letters, 185: 111-119.

Hong, Y.T., et al., 2003: Correlation between Indian Ocean summer monsoon and North Atlantic climate during the Holocene, Earth and Planetary Science Letters, 211: 371380.

Hong, Y.T., Hong, B., Lin, Q.H., Shibata, Y., Hirota, M., Zhu, Y.X., Leng, X.T., Wang, Y., Wang, H. and Yi, L., 2005: Inverse phase oscillations between the East Asian and Indian Ocean summer monsoons during the last 12000 years and paleo- El Niño, Earth and Planetary Science and Letters, 231: 337-346.

Hong, Y.T., Hong, B., Lin, Q.H., Shibata, Y., Zhu, Y.X., Leng, X.T. and Wang, Y., 2009: Synchronous climate anomalies in the western North Pacific and North Atlantic regions during the last 14,000 years, Quaternary Science Reviews, 28: 840-849.

Lee, X.Q., et al., 2005: Carbon isotope of bulk organic matter: A proxy for precipitation in the arid and semiarid central East Asian, Global biogeochemical cycles, 19, GB4010, doi:10.1029/2004GB002303.

Ménot-Combes, G., Burns, S.J. and Leuenberger, M., 2002: Variations of ${ }^{18} \mathrm{O} /{ }^{16} \mathrm{O}$ in plants from temperate peat bogs (Switzerland): implications for paleoclimatic studies, Earth and Planetary Science Letters, 202: 419-434.

McClymont, E., Pendall, E. and Nichols, J., 2010: Stable isotopes and organic geochemistry in peats: tools to investigate paleohydrology, paleotemperature and biogeochemistry, PAGES news, 18(1).

Reimer, P.J., et al., 2004: Residual delta ${ }^{14} \mathrm{C}$ around 2000 year moving average of IntCal04, Radiocarbon, 46: 1029-1058.

Schleser, G.H., 1995: Parameters determining carbon isotope ratios in plants, In: Frenzel, B., Stauffer, B. and Weiss, M.M. (Ed.), Paläoklimaforschung 15: 71-96, Strasbourg, France.

Sun, H.1., 1996: Formation and Evolution of Qinghai-Xizang Plateau, Shanghai Press, Shanghai: pp. 101-146.

Sun, S. and Yin, M., 1999: Subtropical high anomalies over the Western Pacific and its relations to the Asian monsoon and SST anomaly, Advances in Atmospheric Sciences, 16: $559-568$.

Tao, S. and Chen, L., 1987: A review of recent research on the East Asian summer monsoon 
in China, In: Chang, C.P. and Krishnamurti, T.N. (Ed.), Monsoon Meteorology, Oxford, Oxford University Press: pp. 60-92.

Teller, J.T., Leverington, D.W. and Mann, J.D., 2002: Freshwater outbursts to the oceans from glacial Lake Agassiz and their role in climate change during the last deglaciation, Quaternary Science Reviews, 21: 879-887.

Wang S. and Zhu J., 2006: Studies of chronology of millennial time scale climate oscillation in the Holocene, Advances in Climate Change Research, 2 (Suppl. 1): 73-76.

Wang, G., Feng, X., Han, J., Zhou, L., Tan, W. and Su, F., 2008: Paleovegetation reconstruction using $\delta^{13} \mathrm{C}$ of soil organic matter, Biogeosciences, 5: 1325-1337.

Wu, G.X., Chou, J.F., Liu, Y.M., Zhang, Q.Y. and Sun, S.Q., 2003: Review and prospect of the study on the subtropical anticyclone, Chinese Journal of Atmospheric Sciences, 27(4): 503-517.

Yin, M. and Sun, S., 2000: A study on the response of subtropical high over the Western Pacific on the SST anomaly, Chinese Journal of Atmospheric Sciences, 24(2): 193-206. 